\title{
DUSZPASTERSKI SYNOD ARCHIDIECEZJI KRAKOWSKIEJ
}

Na lata $1972-1979$ przypada 900 rocznica pasterzowania w Krakowie św. Stanisława biskupa, który w obronie ładu moralnego w Polsce poniósł męczeńską śmierć z rąk króla Bolesława Śmiałego. Kardynał Karol Wojtyła, Arcybiskup Metropolita Krakowski postanowił uczcić tę pamiętną rocznicę poprzez zwołanie synodu diecezjalnego, którego zadaniem byłoby wprowadzenie w życie na terenie archidiecezji krakowskiej uchwał Soboru Watykańskiego II. Prace Synodu zostały zaplanowane na siedem lat. Decyzja odbycia tak długiego Synodu, bez precedensu w ciągu ponad sześciowiekowej znanej nam historii synodów w Kościele Krakowskim, miała swe szczególne uzasadnienie w tym, co można było nazwać potrzebą chwili. Chodziło o właściwe poznanie, wejście niejako $w$ ducha Soboru i o przemianę życia religijnego wspólnoty Kościoła Krakowskiego w tym właśnie duchu. Nie można było tej przemiany osiągnąć drogą zarządzeń biskupich, chociażby najsłuszniejszych, bo w dzisiejszych czasach jest to sposób mało skuteczny, dlatego też Ksiądz Kardynał zdecydował się na działanie stopniowe, długotrwałe, polegające na próbie przekonania do wskazań Soboru szerokich kręgów duchowieństwa i katolików świeckich. Takie przedsięwzięcie wymagało sporo czasu i poważnego wysiłku.

\section{POWOEANIE I DZIAEALNOSĆ KOMISJI PRZYGOTOWAWCZEJ}

Mając to na uwadze Kardynał Karol Wojtyła już 8 maja $1971 \mathrm{r}$. powołał Komisję Przygotowawczą Synodu, złożoną z 12 osób reprezentujących różne środowiska archidiecezji, w tym także i katolików świeckich. Zadaniem tej Komisji, którą z nominacji Ordynariusza kierował Ks. Prof. E. Florkowski, było opracowanie koncepcji Synodu i jego struktury, wstępny sondaż opinii duchowieństwa i świeckich co do tematyki prac Synodu, a nadto przygotowanie Statutu i Regulaminu Synodu.

W ciągu roku pracy Komisja Przygotowawcza spełniła powierzone jej zadania. Zdecydowanie opowiedziała się ona za pastoralnym charakterem Synodu, przewidując przy tym, że zakończy się on opracowaniem dokumentów, w których zostaną zawarte również postanowienia prawne. Synod, zdaniem Komisji, będzie miał 
charakter duszpasterski wówczas, kiedy będzie się starał angażować wszystkich, zarówno duchownych jak i świeckich do pracy nad uczeniem się Soboru, w małych grupach studyjnych o różnorodnym profilu. W całości winien się stać dobrze przemyślaną akcję duszpasterską, zmierzającą do ukształtowania żywotnych wspólnot apostolskich. Na marginesie uczenia się Soboru można będzie wysnuć wnioski praktyczne dotyczące różnych dziedzin życia religijnego diecezji i pracy duszpasterskiej, które zostaną przez Synod przedstawione Ordynariuszowi, by w oparciu o szeroką konsultację ogółu wiernych w archidiecezji mógł podjąć ostateczne decyzje.

Pobieżne badania opinii publicznej przeprowadzone przez Komisję wykazały potrzebę zwołania Synodu, ujawniły też niektóre trudności, jakie mogą stanąć na drodze jego działania. W oparciu o konsultacje z reprezentatywnym zespołem socjologów stwierdzono, że przeprowadzenie pełnego sondażu opinii i szerszych badań aktualnego stanu życia religijnego w archidiecezji we wszystkich jego aspektach jest niemożliwe i to zarówno ze względu na brak ludzi i funduszów na ten cel, jak również z powodu braku czasu na uzyskanie miarodajnych i użytecznych dla Synodu danych. Zespół socjologów zalecił natomiast, by wykorzystać dla poznania aktualnego stanu życia religijnego te informacje, które już są do dyspozycji, zwłaszcza w Kurii diecezjalnej, a dotąd nie zostały należycie przeanalizowane. Chodziło tu głównie o różne sprawozdania nadsyłane do Kurii, protokoły wizytacji biskupich itp.

Komisja Przygotowawcza opracowała też Statut i Regulamin Synodu, w których to dokumentach zostały określone szczegóły dotyczące celu •i środków działania Synodu.

\section{STATUT I REGULAMIN SYNODU}

Synod postawił sobie za cel wzbogacenie wiary i pełniejsze ukształtowanie postaw chrześcijańskich ogółu duchowieństwa i wiernych archidiecezji. Dlatego też do udziału w Synodzie zostali zaproszeni wszyscy członkowie Kościoła Krakowskiego, duchowni i świeccy, którzy zdecydują się na pewien wysiłek i podejmą wraz z innymi pracę polegającą na zapoznaniu się i zapoznaniu innych $\mathrm{z}$ nauką Soboru Watykańskiego II, wspólnym zastanowieniu się nad możliwościami i sposobami wprowadzenia jej w życie, głównie we własnym, najbliższym otoczeniu.

Struktura Synodu została określona następująco: na czele Synodu stoi Biskup Ordynariusz, wspomagany przez Komisję Główną, której członków sam mianuje. Komisja ta ma za zadanie koordynować całość prac synodalnych, utrzymywać łączność z Ordynariuszem i troszczyć się o dynamiczny charakter Synodu. Komisji 
Głównej podlegają tzw. Komisje Robocze, których zadaniem jest: opracowanie nauki Soboru Watykańskiego II w formie przystępnych referatów lub materiałów do dyskusji, niesienie pomocy tzw. Synodalnym Zespołom Studyjnym w zapoznaniu się z autentyczną myślą Soboru i opracowanie projektów uchwał synodalnych, $\mathrm{z}$ uwzględnieniem nadesłanych $\mathrm{z}$ terenu propozycji. Rolę konsultatywną pełnią w Synodzie Komisje Rzeczoznawców, one też stanowią organ czuwający nad tym, by teksty propozycji synodalnych były zgodne $z$ zasadami nauki i karności kościelnej.

Główny ciężar prac Synodu spoczywa jednak na Synodalnych Zespołach Studyjnych. Zespoły te złożone z osób duchownych czy świeckich, pod kierownictwem kapłana lub przy jego asystencji, studiują naukę Soboru Watykańskiego II, rozważają na jej tle własną sytuację życiową i problemy środowiska w którym pracują, starają się znaleźć i przekazać swe doświadczenie innym. Na etapie pracy w Synodalnych Zespołach Studyjnych ma być osiągnięty właściwy cel duszpasterski Synodu. Rezultat przemyśleń tych zespolów będzie pomocą do opracowania projektów uchwał synodalnych, które po dyskusji zostaną przedstawione zebraniu plenarnemu Synodu.

Zebranie plenarne Synodu stanowi najpełniejszą reprezentację Ludu Bożego archidiecezji. Biorą w nim udział wszyscy członkowie komisji synodalnych, kierownicy Synodalnych Zespolów Studyjnych oraz inni duchowni i świeccy wezwani osobiście przez Ordynariusza. Zebranie plenarne, które zwołuje Ordynariusz, uchwala i przedstawia Biskupowi Ordynariuszowi ostateczne projekty uchwał synodalnych.

\section{PRZEBIEG PRAC SYNODU}

Oficjalnego otwarcia Synodu dokonał Kardynał Wojtyła dnia 8 maja 1972 r. w katedrze św. Wacława na Wawelu, w obecności ponad 1100 uczestników i zaproszonych gości. Podczas uroczystości inauguracyjnej Komisja Przygotowawcza złożyła sprawozdanie ze swej działalności, odczytano Statut i Regulamin Synodu, a Ksiądz Kardynał zatwierdził te dokumenty i mianował przewodniczącym Komisji Głównej Ks. Bpa St. Smoleńskiego. Równocześnie otrzymali nominacje przewodniczący siedmiu Komisji Roboczych i trzech Komisji Rzeczoznawców.

W przemówieniu wygłoszonym $z$ tej okazji Ks. Kardynał jeszcze raz wyjaśnił powody dla których prace Synodu zostały połączone z obchodami 900 rocznicy pasterzowania w Krakowie św. Stanisława. "Tak bowiem jak On (tzn. św. Stanisław) - powiedział m. in. Ks. Kardynał - na miarę swoich czasów, starał się doprowadzić wiarę naszych przodków do własnej dojrzałości, tak i nam 
Sobór Watykański II dał wskazania, rzucił wezwanie, ażebyśmy wiarę naszą doprowadzili do takiej dojrzałości, jakiej domaga się wiara naszych czasów. Św. Stanisław zaznaczył również w dziejach Ludu Bożego na naszej ziemi polskiej tę szczególną więź, jaka musi zachodzić pomiędzy wiarą a moralnością. Wiarą a moralnością jednostki, wiarą i moralnością społeczeństwa. I to jest również głębokie źródło natchnienia. Cały bowiem wysiłek, zmierzający do pogłębienia i wzbogacenia wiary, musi się mierzyć także uczynkami z niej płynącymi. Podejmując dzieło Synodu, podejmujac w tym dziele Synodu zasadniczy cel wzbogacenia i pogłębienia naszej wiary, uczynienia jej świadomą i dojrzałą, na miarę naszych czasów, pragniemy, ażeby ta wiara wyraziła się również dojrzałą, chrześcijańską odpowiedzialnością".

Począwszy od inauguracji Synod zbierał się co roku w uroczystość św. Stanisława w katedrze na Wawelu, by odbyć zebranie plenarne z udziałem ok. 1300 osób, wśród których przeważali wyraźnie katolicy świeccy. Zebrania plenarne Synodu u grobu św. Stanisława miały zawsze charakter informacyjny, stanowiły jednak równocześnie świadectwo wiary i podjętego trudu pracy synodalnej.

W pierwszym roku pracy, obok niezbędnych kroków organizacyjnych, których skutkiem było utworzenie Sekretariatu Synodu, Komisji Roboczych i Komisji Rzeczoznawców, przystąpiono przede wszystkim do tworzenia Synodalnych Zespołów Studyjnych. Powstawały one w różny sposób: bądź przekształcały się $z$ istniejących już w parafiach wspólnot, bądź też o wiele częściej, formowały się od podstaw. Pomocą w tworzeniu zespołów, stanowiących główny element struktury Synodu, służyli zarówno sam Ksiądz Kardynał, który przeprowadził na ten temat spotkania ze wszystkimi księżmi archidiecezji podczas konferencji rejonowych od października do grudnia 1972 r., jak również członkowie Komisji Głównej, kontaktując się bezpośrednio $\mathrm{z}$ istniejącymi lub formującymi się zespołami w terenie. Wynikiem tych wysiłków było powstanie $w$ pierwszym roku działalności Synodu 325 Synodalnych Zespołów Studyjnych, praktycznie rzecz biorąc we wszystkich dekanatach archidiecezji, z udziałem w ich pracach ok. 4000 osób.

Komisja Główna starała się w tym czasie określić metodę pracy $w$ zespołach i troszczyła się o dostarczenie im odpowiednich materiałów ułatwiających studium Vaticanum II. Praca Kard. Karola Wojtyły pt. U podstaw odnowy. Studium o realizacji Vaticanum II, wydana w Krakowie w 1972 r. a pomyślana przez Autora jako „vademecum, naprowadzające na różne dokumenty Vaticanum II... pod kątem wcielenia w życie i wiarę Kościoła", stanowiła $\mathrm{w}$ tej mierze najpewniejszy materiał, ale nie dla wszystkich wystarczająco przystępny, stąd też istniała potrzeba tworzenia łatwiejszych opracowań. 
Po II zebraniu plenarnym w maju 1973 r. Synod kontynuowal wysiłki nad tworzeniem nowych Zespołów Studyjnych tak, że w maju 1974 r. ich ilość wzrosła do 497, w czym było 449 zespołów parafialnych a 48 o charakterze ponadparafialnym. Po raz pierwszy na III zebraniu plenarnym Synodu, dnia 8 maja 1974 r. zabrali głos przedstawiciele Synodalnych Zespołów Studyjnych, informując o swojej pracy i zainteresowaniach apostolskich.

Równocześnie w drugim roku pracy Synod zajął się dwoma innymi zagadnieniami: przygotowaniem archidiecezji do powołania Duszpasterskich Rad Parafialnych oraz opracowaniem koncepcji synodalnego dokumentu końcowego. Problemem Duszpasterskich Rad Parafialnych zajęla się w archidiecezji najpierw Rada. Kapłańska, potem Synod przeprowadził na ten temat szeroką konsultację poprzez Synodalne Zespoły Studyjne, które wypowiedziały się w tej sprawie w specjalnej ankiecie. Konsultacja ta wykazała, że sprawa jest ważna ale i trudna, że wymaga czasu i poważnego wysiłku, jeśli te Rady mają spełniać swe zadanie w duchu Soboru. $Z$ wolna jednak, mimo trudności zaczęły powstawać takie Ra$\mathrm{dy}$, albo samodzielnie, ale w oparciu o działający w parafii Synodalny Zespół Studyjny. Otrzymywały one indywidualną aprobatę Księdza Kardynała, a dopiero 8 maja 1975 r. ukazał się Jego dekret zatwierdzający Statut Duszpasterskich Rad Parafialnych, opracowany przez Komisję Główną Synodu.

Prace nad koncepcją dokumentu końcowego Synodu nie przekroczyły jeszcze w tym czasie wstępnego etapu, niemniej na III zebraniu plenarnym dnia 8 maja 1974 r. zarys tego planu, tak pod względem treści jak i formy opracowania, został przedstawiony. Wprawdzie Ksiądz Kardynał w swoich wypowiedziach do czlonków Komisji Głównej w dniu 4 grudnia 1973 r. wyraźnie nakreślił plan takiego dokumentu, to jednak Komisja Główna potrzebowała jeszcze kilku miesięcy na opracowanie jego szczegółów. Ostatecznie dnia 26 października 1974 r. przyjęto zasadę, że Synod Krakowski powinien się wypowiedzieć tylko w takich sprawach poruszonych na Soborze Watykańskim II, które w dobie obecnej mają szczególne znaczenie dla Kościoła Krakowskiego. Jako klucz układu dokumentów synodalnych przyjęto tria munera, prawdę wskazaną przez Sobór o uczestnictwie całego Ludu Bożego w·potrójnym posłannictwie, w potrójnej misji zbawczej Chrystusa: prorocko-nauczycielskiej, kapłańskiej i królewsko-pasterskiej.

Wybór tego klucza, zasugerowany przez Kardynała Wojtyłę, klucza trudnego i nie od razu dla wszystkich zrozumiałego, należy uznać za duże osiągnięcie Synodu Krakowskiego, przede wszystkim dlatego, że jest to klucz bardzo soborowy.

Cała tradycja teologiczna Kościoła przed Soborem była zbudowana wokól laski i grzechu, jako przesłanek wiodących, z człowiekiem jako dzieckiem Bożym pośrodku. Główną problematyką 
życia religijnego była problematyka stanu dziecięctwa Bożego, adopcji lub też jej straty. Oczywiście że Sobór nie skreślił tej problematyki z teologii, ale poprzez wskazanie na tria munera bardzo ją wzbogacił. Wzbogacenie to polega przede wszystkim na ukazaniu prawdy o Ludzie Bożym, o jego powszechnym uczestnictwie w dziele zbawczym Chrystusa. Tria munera wskazują ponadto na społeczny charakter powolania, posłannictwa i odpowiedzialności wszystkich chrześcijan za życie religijne, co daje bardzo zasadnicze postawy apostolstwu świeckich.

W ramach każdego munus ustalono tematy-hasła, które polecono opracować według następującego schematu: $1^{\circ}$ - przesłanki teologiczne tematu; $2^{\circ}$ - opis aktualnej sytuacji Kościoła Krakowskiego $\mathrm{w}$ tej dziedzinie; $3^{\circ}-$ wskazania pastoralne i ewentualne postanowienia prawne, zmierzające do ukierunkowania życia religijnego w ogóle, a pracy duszpasterskiej w szczególności, ponadto do: możliwie jednolitego ustawodawstwa diecezji na przyszłość.

Tematy opracowane w ramach każdej z trzech misji postanowiono poprzedzić ogólnym dokumentem wprowadzającym, którego zadaniem byłoby określenie Kościoła Krakowskiego jako wspólnoty partykularnej, w której uobecnia się i urzeczywistnia Kościół powszechny. Ten wstępny dokument ogólny, obok części teologicznej, uwzględniającej problematykę uczestnictwa Kościoła partykularnego w potrójnej misji zbawczej Chrystusa, zawierałby zwięzły rys historyczny archidiecezji i równie zwięzłą charakterystykę stanu obecnego Kościoła Krakowskiego.

Pierwsze dwie wersje tego dokumentu zostały opracowane już na przełomie 1974 i 1975 r., a ich ostateczną redakcję odłożono na później, licząc się z tym, że po opracowaniu wszystkich dokumentów, zajdzie potrzeba pewnych zmian w dokumencie wstępnym.

Tematy-hasła, podane początkowo przez Komisję Główną w ramach każdej z misji, przekształciły się z czasem we właściwe tytuły zagadnień,, których opracowania podjął się Synod, ale mimo wszystko każdy $\mathrm{z}$ tych tytułów musi być rozumiany $\mathrm{w}$ kontekście calego dokumentu synodalnego czy raczej wszystkich jego dokumentów, a zwłaszcza w kontekście tej misji, w jakiej został ujęty. Tak więc dokumenty synodalne zostały opracowane pod następującymi tytułami:

I. W ramach misji prorockiej: 1. Głoszenie Słowa Bożego. 2. Przekaz i rozwój wiary w rodzinie. 3. Katechizacja. 4. Posłannictwo teologii w kształtowaniu życia wiary Kościoła Krakowskiego. 5. Instytuty zakonne w służbie Kościoła Krakowskiego. 6. Działalność misyjna Kościoła Krakowskiego.

II. W ramach misji kapłańskiej: 1. Eucharystia źródłem życia chrześcijańskiego. 2. Chrzest i bierzmowanie jako sakramenty wprowadzające w świętość chrześcijańską. 3. Udział chrześcijanina w. Chrystusowym cierpieniu i w Jego zwycięstwie nad śmiercią - 
sakrament namaszczenia chorych. 4. Udział chrześcijanina w Chrystusowym zwycięstwie nad grzechem - pokuta i sakrament pokuty. 5. Sakrament kapłaństwa. 6. Małżeństwo chrześcijańskie. 7. Uświęcenie czasu.

III. W ramach misji pasterskiej: 1. Dziecko we wspólnocie Kościoła. 2. Młodzież w życiu Kościoła Krakowskiego. 3. Rodzina. 4. Apostolstwo miłości Kościoła Krakowskiego. 5. Przepojenie kultury współczesnej duchem Ewangelii. 6. Chrześcijanin w pracy zawodowej. 7. Odpowiedzialność chrześcijan za budowę i odnowę świata. 8. Struktury diecezjalne. 9. Matka Boża w życiu Kościoła Krakowskiego.

Ten zwięzły wykaz tematów, a zarazem roboczych tytułów dokumentów synodalnych musi wystarczyć, bo brak miejsca na szersze jego uzasadnienie, zwłaszcza zaś na wskazanie, dlaczego niektóre $\mathrm{z}$ tych tematów umieszczono $\mathrm{np}$. w grupie zagadnień $\mathrm{z}$ zakresu misji prorockiej, a nie kapłańskiej. Synod w każdym razie takie uzasadnienie znalazł i wydaje się, że można je uznać za przekonujące.

Po ustaleniu ogólnego planu dokumentów synodalnych, po wyznaczeniu tematów i po powołaniu Zespołów Redakcyjnych, które przejęły zadania ciążące początkowo na Komisjach Roboczych a wszystko to miało miejsce na przełomie 1974 i 1975 roku Synod przystąpil do ostatniej fazy swych prac, to znaczy do redagowania dokumentów. Przyjęto taki tok postępowania, że każdy tekst przygotowany przez Zespół Redakcyjny podlega ocenia Komisji Głównej, która jeśli uzna go za wystarczający pod względem treści i formy, przesyła go Synodalnym Zespołom Studyjnym do konsultacji. Uwagi Zespołów Studyjnych poczynione na piśmie lub podczas specjalnych tematycznych dyskusji organizowanych przez Sekretariat Synodu, wędrują zawsze, po zapoznaniu się z nimi przez Komisję Główną, do Zespołu Redakcyjnego, który musi je przeanalizować i ewentualnie uwzględnić w nowej wersji projektu. Nic więc dziwnego, że niektóre projekty dokumentów Synodu Krakowskiego, zanim jeszcze zostały przesłane do Synodalnych Zespołów Studyjnych, posiadały trzy lub cztery wersje, a za definitywną, którą postanowiono poddać głosowaniu, uznano czasem dopiero piątą lub szóstą wersję projektu. Przed głosowaniem, zatwierdzoną przez Komisję Główną wersję projektu przesyłano do zaopiniowania Komisjom Rzeczoznawców.

W miarę powstawania projektów, a należy zaznaczyć, że starano się je tworzyć po kolei, według ustalonego porządku w ramach każdego munus, zrodziła się potrzeba przyspieszenia prac Synodu przez częstsze zwoływanie zebrań plenarnych, zaszła też konieczność uzyskania zezwolenia Stolicy Apostolskiej na dopuszczenie katolików świeckich do pełnego udziału w Synodzie poprzez głosowanie, bo obowiązujący nadal Kodeks Prawa Kano- 
nicznego nie przewiduje w ogóle udziału katolików świeckich w synodzie.

Mimo podjęcia prac redakcyjnych, które zresztą początkowo szły bardzo opornie, IV i V zebranie plenarne Synodu, a więc dnia 8 maja 1975 r. i 8 maja 1976 r., które odbyły się w katedrze na Wawelu, miały charakter informacyjny, z tym jednak, że dotyczyły już dość szczegółowo treści powstających dokumentów. Obok relacji na temat projektów przyszłych uchwał, programy tych zebrań przewidywały udział Synodalnych Zespołów Studyjnych, które prezentowały na nich własny dorobek apostolski w zakresie tych problemów, nad którymi aktualnie dyskutował Synod.

życie synodalne archidiecezji nabrało rumieńców w początkach 1977 r., kiedy Synod wystąpił z inicjatywą organizowania we wszystkich parafiach tzw. niedziel synodalnych. Polegało to na systematycznym zapoznawaniu wiernych $z$ problematyką rozważana przez Synod w oparciu o materiały nadesłane przez Sekretariat. Tej informacji $z$ ambony była poświęcona jedna niedziela $w$ miesiącu. Ze strony wiernych Synod oczekiwał wypowiedzi na piśmie na wskazany w ten sposób temat i rzeczywiście takie wypowiedzi otrzymywał, wykorzystując ich treść w pracach redakcyjnych.

Równocześnie niemal $\mathrm{z}$ niedzielami synodalnymi, bo w lutym 1977 r., nastąpiło jeszcze jedno spotkanie wszystkich księży archidiecezji z Księdzem Kardynałem na konferencjach rejonowych, których tematyka dotyczyła Synodu i zbliżającej się 900 rocznicy śmierci św. Stanisława.

16 kwietnia 1977 r. odbyło się VI zebranie plenarne Synodu, tym razem po raz pierwszy w gościnnym opactwie oo. cystersów w Krakowie-Nowej Hucie-Mogile. Zebranie to, zwołane ze względów lokalowych we wspaniale odrestaurowanej i obszernej auli opactwa, było poświęcone głosowaniu nad dwoma pierwszymi projektami dokumentów synodalnych $\mathrm{z}$ grupy tematycznie obejmującej misję prorocką. Już wówczas, a później z okazji każdej podobnej sesji synodalnej, głosowanie każdego projektu było poprzedzone relacją ilustrującą proces powstawania tekstu wspólnym wysiłkiem redaktorów i Synodalnych Zespołów Studyjnych. W każdym takim zebraniu przewidywano ogłoszenie wyników głosowania i informację na temat najbliższych zamierzeń Synodu.

Oprócz zebrań plenarnych poświęconych głosowaniu nad projektami dokumentów synodalnych, które odtąd zwoływano do opactwa oo. cystersów w Krakowie-Nowej Hucie-Mogile, doroczne zebrania plenarne $z$ okazji uroczystości św. Stanisława, z programem informacyjnym gromadziły się w katedrze na Wawelu.

$\mathrm{Na}$ zebrania poświęcone głosowaniu Ksiądz Kardynał zapraszał osobiście za każdym razem ok. 450 osób, wśród których co najmniej 200 katolików świeckich. Stało się to możliwe dzięki zezwo- 
leniu, jakiego udzieliła Stolica Apostolska dekretem z dnia 22 kwietnia $1975 \mathrm{r}$.

VI zebranie plenarne Synodu odbyło się w opactwie mogilskim pod nieobecnośé chorego wówczas Księdza Kardynała..Uczestniczył On natomiast dnia 7 maja 1977 r. w VII zebraniu plenarnym na Wawelu, dnia 3 grudnia 1977 r. w Krakowie-Nowej Hucie-Mogile w VIII zebraniu plenarnym i ostatni raz w samą uroczystość św. Stanisława, dnia 8 maja 1978 r. w IX zebraniu plenarnym, które rozpoczęło się w opactwie oo. cystersów w Mogile, a zakończyło u grobu św. Stanisława na Wawelu.

Podczas wszystkich tych zebrań Synod zdołał uchwalić dziewięć dokumentów, a to: sześć z tematyki misji prorockiej i trzy $\mathrm{z}$ tematyki misji kapłańskiej. Prace Synodu przebiegały w tym czasie normalnie, z tym tylko, że począwszy od VII zebrania plenarnego, Komisje Redakcyjne uchwalonych już dokumentów, uzupełniały pod kierunkiem Komisji Głównej uchwalony tekst poprawkami zgłoszonymi w czasie głosowania. Wprowadzenie tych poprawek, stosunkowo licznych, było już ostatnią interwencją w teksty uchwał, jeśli nie liczyć przewidzianych pod koniec Synodu poprawek stylistycznych i potrzebnego ujednolicenia terminologii, czym zajmuje się specjalny zespół powołany do istnienia w grudniu $1978 \mathrm{r}$.

Nie było już dane Kardynałowi Wojtyle wziąć udziału w X zebraniu plenarnym Synodu, które Jego powagą odbyło się w Krakowie-Nowej Hucie-Mogile i na którym uchwalono trzy dalsze dokumenty $\mathrm{z}$ tematyki misji kapłańskiej. Nie było $\mathrm{Mu}$ dane, bo był to dzień 14 października $1978 \mathrm{r}$. W czasie kiedy Synod gromadził się w Krakowie, by uczynić dalszy krok w swej pracy, której On był natchnieniem, w Rzymie kardynałowie weszli już na konklawe. Uczestnicy zebrania plenarnego przesłali Księdzu Kardynałowi telegram, zapewniając Go o gorącej modlitwie w intencji wyboru godnego Następcy św. Piotra. W dwa dni później, w pamiętny wieczór 16 października świat dòwiedział się, że to właśnie On, Arcybiskup Metropolita Krakowski został tym Następcą i przybrał imię Jana Pawła II.

$\mathrm{Z}$ prawnego punktu widzenia Synod Krakowski uległ przerwaniu, ale wkrótce jego kontynuacji podjął się najpierw Wikariusz Kapitulny Archidiecezji Krakowskiej Ks. Bp Julian Groblicki, uzyskując na to dnia 21 listopada 1978 r. zgodę Stolicy Apostolskiej, później zaś wznowił działalność Synodu nowy Arcybiskup Metropolita Krakowski Ks. Franciszek Macharski, wydając w tej sprawie dekret dnia 1 marca $1979 \mathrm{r}$. 
Do chwili obecnej (7. IV. 1979) Synod uchwalił sześć dalszych dokumentów, odbywając w Krakowie-Nowej Hucie-Mogile dwa zebrania plenarne: 16 grudnia 1978 r. XI-te, pod przewodnictwem Ks. Biskupa Juliana Groblickiego jako Wikariusza Kapitulnego i 3 marca 1979 r. XII zebranie, pod kierunkiem Ks. Franciszka Macharskiego, Arcybiskupa Metropolity Krakowskiego. Dnia 8 maja 1979 r. Synod Krakowski przystąpi do głosowania nad ostatnimi czterema przygotowanymi przez siebie dokumentami.

KS. TADEUSZ PIERONEK 